\title{
Sustainability of the Nigerian Environmental Resources Conservation and Management: Interrogating the Principles of Conservation in Biblical Christian Perspective
}

\author{
Dr. Rimamsikwe Habila Kitause, \\ Lecturer, Department of Christian Religious Studies, \\ Faculty of Arts, Taraba State University, Jalingo, Nigeria \\ Dr. (Mrs) Comfort Kamimi Gemade, \\ Dr. (Mrs) Franca Shiminenge Jando, \\ Lecturer, Department of Religion and Cultural Studies, \\ Benue State University, Makurdi, Nigeria
}

Doi:10.19044/esj.2020.v16n29p51 ＵRL:http://dx.doi.org/10.19044/esj.2020.v16n29p51

\begin{abstract}
Human environments everywhere are seriously being abused due to different kinds of environmental pollutions which man indiscriminately unleashes on them thereby making these environments almost unsafe and inhabitable engendering unfavourable atmosphere for man's survival. This paper examines how depreciated Nigerian environmental resources have become nowadays and how this is contributing in making life unbearable in this $21^{\text {st }}$ century. This study adopts descriptive and analytical approaches which were basically employed to describe the phenomenon of environmental destruction and conservation, interpret and analyse data in the study. There were also the use of personal observations, in-depth interviews and focused group discussions on the subject. It was found out that due to the expansion of Christianity which finds expression in the proliferation of churches and ministries in Nigeria, encroachment of all kinds into forest reserve areas is steadily ongoing which is the destruction of the environments. Each denomination and ministry competes over acquisition of large land mass running to hundreds of hectares for either camp grounds for their church retreats or for the establishments of church-based business centres, filling stations, bakery, Television centres, primary schools, secondary schools, colleges and universities thereby depleting the environments. The results show that there is a destruction of the environment on the one hand and the conservation of same on the other hand. The findings show the environmental crisis devastates living organisms which is gradually engendering the total
\end{abstract}


collapse of human environment if no quick attention is given to its proper management. The paper submits that the quicker attention is given in taking better care of the environmental resources by the government, organizations and individuals, the sooner the world becomes inhabitable for human beings.

Keywords: Conservation, Environment, God, Man, Nigeria, Sustainability, Pollution

\section{Introduction}

Environmental resources abound in Nigeria in varying degrees and need to be conserved in line with divine and human principles of preservation. The earth and all of God's creations are gifts to human kind. These gifts of natural endowment are to be received and put to use meekly and wisely too. It is said that God's creative action in Genesis chapter one gave rise to human habitat categorized as heaven and earth. As far as the human life is concerned, the earth remains man's place of temporal abode for now. So, God in his magnanimity graciously created the earth to be inhabited by man and all the other organisms. The earth is where man temporarily resides and carries out his activities. Man's activities either conserved or destroyed the environmental resources depending on how he puts them to use.

To maximize the earth's full potentials, humans are to properly harness and care for their own environment for it not to become hazardous for their dwellings and sustenance. The Christian religious for instance is known for her roles in maintaining as well as depleting the environments. In its bid to expand its frontiers, Christianity has overspread almost everywhere in Nigeria by acquiring massive hectares of land for the establishment of schools, theological colleges, universities, monasteries, camp grounds, aged people's homes, hospitals, farm of different kinds, airstrips, mission stations, quarries, business centres, burial grounds among so many others too numerous to mention. Equally, the Christian church as agent of transformation has constructed roads to many towns and settlements, constructed bridges across many rivers, constructed drainages to solve problems of erosions and planted orchard of different fruit trees

This indicates that there is a kind of relationship that exists between humans and the earth for the overall interest of harmonious coexistence. Nature as gifts to humans must be handled with care so as to avoid environmental crisis. How this has been realized in Nigeria especially when viewed vis-à-vis some biblical examples of conservation forms the main thesis of this paper. The paper tries to express the religious perspective on man's initiatives in the conservation and management of environmental resources with a view to suggesting better ways of preserving the Nigerian environment 
that can stand the test of time in this $21^{\text {st }}$ century. The paper unfolds under the following sub-headings:

\section{Conceptual Clarification of Terms}

For the purpose of clarity, the meanings of the following key words are clarified. According to Longman Dictionary of Contemporary English, the word 'sustain' from where sustainable emanates connotes to make something continue to exist or happen for a period of time. When sustainable is used in relation to environment, it means the ability to make the environment to continue existing without causing damage to it. Environmental Resources could mean all the physical environments put together such as the air, water and land on earth including natural resources such as oil and coal among several others. Conservation is the protection and prevention of natural things such as animals, plants, forests and a host of others from being destroyed. In other words, to conserve the environment is to protect it and prevent it from changing negatively or from being damaged. Management of environmental resources has to do with controlling the rate at which our physical environments are being depleted and harmed.

\section{Environmental Resources Challenges in Nigeria}

Nigeria is richly endowed with abundance environmental resources which if judiciously utilized will increase the comfort and longevity of its inhabitants. Life is said to flourish at its best when there is a good atmospheric condition for its survival. Everything shrinks back in its ability to blossom when challenged by hazards that threatens its existence. God in his own wisdom and economy has put in place every favorable condition necessary for every living organism to thrive in their respective habitats. A damaged to one environment is a damaged to another. This signifies that there is a relationship between man, plant and other living organisms in the environment which is the reason living organisms co-exist on the planet earth. According to Anyacho (2003) the planet is one family. To him whatever affects one part of the globe has effects on the other parts of the globe. As a house, the planet earth accommodates every living being in it conveniently. But when the environment is tampered with, misfortune remains the inescapable repercussion.

In his observation Oyeshola (1995) opines that our planet is currently being "threatened by global warming, ozone depletion, biological diversity loss, deforestation, desertification, environmental disasters and degradation" (p.10). The challenges emanating from the environment threaten human security on earth. People are now frightened because of the unknown. While trying to tackle one environmental problem or the other, man finds himself creating another problem for himself. This means that environmental 
challenges are triggered up by man's activities on the environment. Painting the picture of man's attempt to improve oneself only to create a different problem on the environment, Carson (1962) declares that:

We humanly use modern medicine to lower the death rate for millions only to be faced with population explosion. We spray pesticides and fertilizers to supply food for the growing millions only to kill birds and fish, and pollute our food and water (p.7).

This is the situation that confronts man which is quite worrisome. Population explosion which man creates by improving the quality of life as depict above creates other problems in the society. Population growth leads to poverty which also leads to environmental degradation, pollution, soil erosion and other hazards. For instance, it is said that poverty pollutes the environment by creating environmental stress in different ways.

How this happen is that those who are said to be poor and hungry go about destroying their immediate environments in order to survive. Poverty which is now endemic in Nigeria has been a major challenge in our society. This makes man to device different means of survival and using same in order to escape from poverty. He engages himself in farming and other economic activities. Farming activities encourage cutting down of trees and clearing of forest which destroy some organic and inorganic contents of the soil. Man also rears animals which lead to overgrazing the grassland. This happens by allowing animals to remain on the same spot for too long which endangers the soil. All these culminate in soil erosion.

Similarly, over population is the causal factor of different kinds of pollution in the Nigerian environments. There is air pollution, water pollution, land pollution, oil pollution, noise pollution and pesticide pollution. Pollution causes undesirable changes in the society. Most of these modifications are unpalatable which are harmful to man. For instance, air pollution is responsible for the depletion of ozone layer and the greenhouse leading to global warming. As observed by Anyacho (2003), global warming is caused by billions of carbon dioxide being released to the atmosphere by human activities. Global warming and climate change have serious effects on human existence.

Water and land pollutions affect human and animals health adversely. These pollutions are caused by wastes from industries, human beings, animals, chemicals, sewage and oils among others. Equally, noise pollution from churches, mosques, sirens, carnivals, aircrafts, markets, political rallies, factories and comedies can have many negative effects on human beings as well as on the environment. As noted by Umoren (2011), noise pollution can have an effect on the physical and mental health of persons. He explains how 
one can become impaired of hearing as a result of noise pollution, in his own very words thus:

It is known that the Teutonic membrane [which is the] eardrum has very many hair-like nerves which absorb sound vibrations and transform them to an ordered sound. When this membrane has to absorb sound vibrations which are higher than normal, the hair-like nerves gradually become damaged, and the sensitivity to hearing is affected. Depending on how the nerves are damaged, hearing may eventually become impaired (Umoren 2011, p.147).

This assertion unveils one of the most dangerous effects of noise pollution to the human kind. When the human ear is impaired, it leads to many other things including road and domestic accidents which could have been avoided assuming ones ears function effectively.

Polluting the earth is evil in the perspective of Ukwuije (2010). To his mind, some of the ways to destroy the environment is bush burning, carelessly throwing dust bins around the environment, defecating and urinating around the house and killing all edible animals, plants and insects around us. Excreta and urine contaminate our environment making it inhabitable. In his observation, Okeke (2011) maintains that:

A quick glance at these places [our houses] is an eye sore. It leaves much to be desired. Houses and most living homes are not well kept. Toilets are not flushed and kept clean. In fact, they can be properly described as disease infected areas. Every part of the market is a refuse dump; and yet every type of food items is bought and sold there. Sanitary situation is anything but not what it should be. Public conveniences are not available and where they are, they are not functioning (p.117).

By continuing contaminating the air, water and land, it poises great health threats to man and animals making the earth no longer a safe haven for habitation. Many have rushed to their untimely grave as a result of poor management of the environment.

The environmental challenges transcend that of physical environment to other realms in the human body. Man as the highest of God's creation has been corrupted to some extent. Think of man's indulgence in cigarette smoking which damaged the vital organs in the human body. The x-ray being carried out for medical investigations of patients in hospitals caused untold destructions to systems of the body. Some men and women who bleached to appear fashionable and to be fairer in complexion do so to the detriment of their health. Those who go for plastic surgeries have had their side of the story. 
Millions of people have died prematurely due to their immoral lifestyles in contracting HIV and AIDS and other Sexually Transmitted Diseases. Still many have destroyed their natural body through make-ups out of which many have died in the process.

\section{Environmental Sustainability in Nigeria}

Man has always tried to adopt different strategies in tackling and coping with his environmental challenges in Nigeria. This is what Ukwuije (2010) captures as befriending the earth. Man, in the perspective of God is a tenant on earth. Being a tenant, man automatically assumes the mandate to take care of his immediate environment which is likened to his own personal property where he occupies. The Holy Scriptures affirm that man has been saddled with the responsibility of preserving the earth (Gen. 1:28). God entrusted the stewardship of the planet earth to man because he is the crown of God's creation having been endowed with a high level of intelligence. Man's conservation of the earth redounds to the prolonging of his life on the surface of the earth.

Caring and sustaining the environment remains one of man's worthy and greatest tasks on earth. For the benefit of man himself and other organisms around him, the maintenance of the environment became very imperative. Over the years, man has made concerted attempts at revamping the environment. Conserving the environment entails preserving the health of humans as well as sustaining the environment itself. In their various efforts at conserving the soil, millions of naira has been expended in controlling soil erosion, desertification and deforestation. Rather than causing more harm to the environment through human activities such as logging, mining, hunting, and fishing, successive government have over the years been creating and developing zoos, wildlife, tourism and recreational centers across the country. In addition, there have been efforts in waste management in Nigeria too. According to Okoro (2011), there are generally, 4R Principles of reduce, reuse, recycle and recover of waste management. He reiterates that this principle advocates:

○ Reducing the quantity of waste generated at source through more efficient utilization.

- Reusing the waste in its original form - e.g. chemical containers buy back.

- Recycling waste- e.g. recycling waste paper as toilet rolls, printer cartridges, and

- Recovering waste - e.g. burning waste oil for energy recovery (Okoro, 2011, p.34). 
It is said that the benefit of this process is that it is economic, more sustainable and a healthy approach which ultimately, reduces the quantity of disposal waste to a manageable residue which is truly cheaper to handle. This appears to be the best ways to manage waste in conserving the environment in Nigeria.

In a related development, efforts are being geared towards rehabilitating areas affected by oil spills in Nigeria. This is being carried out by the various Oil Companies operating in Nigeria in collaboration with the federal government of Nigeria. The process involves employing Thermal Desorption Units (TDU) Technology to remediate the soil into slabs and block for re-use. Added to this, there is biodiversity conservation for the sustenance of life in Nigeria. Biodiversity involves a wide range of processes which provides essential goods and services such as food, clothing, medicine, shelter, clean air, fuel, photosynthesis, pollination, nutrient cycling, climate regulation, seashore protection, land purification and habitats.

The fact cannot be denied too that the soil and water in the river line states of Nigeria have been heavily degraded and polluted as a result of the tapping of the Nigerian natural resources. This has affected the socioeconomic and socio-cultural life of the people severely. As explained by Okeke (2011):

Their land loses its fertility, no fish in the sea, animals and birds die in their hundreds as their habitats are destroyed by oil spills. The people are forced to leave their villages and settlements in search of a new place to live. (p.190).

This movement forces the people to abandon their original communities to another one. The search for shelter has made many people to migrate to big towns and cities in Nigeria causing population explosion. The challenge posed by this phenomenon has made government to embark on building housing estates everywhere in Nigeria which cannot also tackle accommodation problems in the Nigerian cities. Equally, government is currently doing her best to stop gas flaring. This is a money guzzling project. Forest conservation policy of government has encouraged tree plantation in Nigeria.

\section{Principles of Conservation in Christian-Biblical Perspective}

It is undisputable that God is the creator and sustainer of all existence. His principles of conserving environmental resources remains a timeless wisdom to man. The Scriptures unravel that as a sustainer, God remains the pacesetter in environmental conservation and management. His injunctions to Adam in Gen. 2:15 betray this fact and further provide some clues and guiding principles on how the earth is to be preserved. According to Ijezie (2011), 
All that the human being is entrusted to do in the garden is to till or work the garden and to watch over it... The responsibility of cultivating and protecting the garden is so onerous that the man (Adam) needs a helper. So God makes the woman to acts as a helper (pp.134-135).

Ijezie further buttresses that the woman comes not just to break man's loneliness but to ease man's burden in the work of service in the garden. As it happens, divine principles concerning environmental conservation are unveiled from God's own dealings and directives to Adam and Noah among others.

Even though, God was determined to destroy the world because of its increasing wickedness and moral decadence, he was also careful not to wipe out everything completely from the surface of the earth. In executing his conservation plans, God went ahead to preserve different seeds of things that mattered in the world then in order to re-populate the earth after its cleansing. Adopting his own principle of conservation, God mandated Noah to build an ark for the purpose of preserving different species of beasts, animals, creeping things, and birds of the air. Noah ark was to contain himself and his family members and every two organisms of every kind which are to be male and female. Here, God's principles of conservation seem to have been implied in his choice of every kind of the organism so selected (Genesis 6:7-8). God's oldest institution in the Bible which is marriage simply explains the reason mankind should not become extinct in the world.

God further revealed to Abraham the significant of mapping out grazing land for his animals. The separation of grazing areas between Abraham and Lot's herdsmen further attest to this fact. Abraham was very rich in cattle and so also his nephew Lot (Genesis 13:2, 5, 8-9). The problem that erupted between Abraham and Lot came as a result of their continual grazing activities on the same spot which eventually degraded that environment culminating in the strife between their herdsmen. The singular facts that herders own their animals individually give room for the judicious management of ranches. Since the ranch they exploit is open access the unmanaged exploitation of the resources between Abraham's herdsmen and Lot's herdsmen leads to separation of the two herders for the land to regenerate. This helps in avoiding conflict in the future.

God's principle of conservation again comes to play in Egypt through Joseph, the son of Jacob. In the land of Egypt, Joseph rose to power after he was given the wisdom of interpreting dreams. This earns him the position of Prime minister in Egypt. As their leader, he mandated and tasked the Egyptians to collect their resources during the time of abundance which was used to saved lives during the time of scarcity (Genesis 11:1-5). 
When the Israelites' stay in Egypt was fulfilled, God set them free from their bondage. In the passage of years, God brought them to the Promised Land; a land said to be flowing with milk and honey. With the continual use of that land, it eventually became overstressed. God again applied his principle of conservation to reduce internal stress on the scare and degraded resources. This is to ensured the continuity and sustainability of his promise to the fourth generations of the Israelites by preserving the land for future use (Exodus 23: 10 - 11). Land conservation principle was thus adopted by God for the Israelites to plough the land for six years and gather in the fruits. On the seventh year, the said land is to be allowed to rest or lie still and fallow for one year for it to regain its strength. It is also to enable the poor as well as the beasts of the field to glean on the fallow land so as to have their own share of whatever they can get from the land in order to eat. This is expressed thus:

And six years thou shalt sow thy land, and shalt gather in the fruits thereof: But the seventh year thou shalt let it rest and lie still; that the poor of thy people may eat: and what they leave the beasts of the field shall eat. In like manner thou shalt deal with thy vineyard and with thy olive yard (Exodus 23:10-11).

\section{The Way Forward}

The efforts at conserving environmental resources in Nigeria as explored in this paper are not exhaustive. So much still need to be done to be able to record more successes along this line. This paper therefore offers the following recommendations in conserving environmental resources in Nigeria.

i. Government alone may not be able to conserve the environment, well able Christian leaders and churches should intensified efforts in revamping the dilapidated Nigerian roads thereby making it more motorable.

ii. Churches should sensitize her teeming parishioners on the need to replace every tree the fell.

iii. Religious leaders to partner with government at all levels to discourage overgrazing in Nigeria.

iv. Government should as a matter of priority equip the Environmental Protection Agency to make their impact to be felt in Nigeria by way of sensitizing the people in the sensible and responsible use of the environment.

v. The National Assembly should urgently enact a law to take care of any environmental offense and to forestall any abuse of the environment.

vi. Government through the Environmental Protection Agency to set up serious Task Forces across the nation to enforce the law which the National Assembly will legislate. 
vii. Proper road network with good drainages should be the target of the federal government also to ease movement and communication in Nigeria.

viii. High and low-cost housing estates and camps may be built in Nigeria to cushion the effects of hardship being faced by low income earners and Internally Displaced Persons (IDPs).

\section{Conclusion}

This paper examined the principles of conservation of environmental resources from Biblical Christian perspective. It studied how man's activities on earth do improve and deplete the environment in his quest for expansion. The study revealed that when the environment is depleted, it becomes unfriendly for human existence. It is noted that the responsibility of conserving environmental resources is the responsibility of all taking into cognizance the fact that it is God himself that has committed the care of the environment to human kind. As discovered, the government has not shown enough commitment in channelling enough resources to Environmental Protection Agency which has been saddled with that responsibility in Nigeria. It is on ground of this that the paper submits that the earlier attention is given by government, organizations and individuals in taking care of environmental resources, the sooner the world becomes inhabitable for human beings to stay.

\section{References:}

1. Alexander, T. D. (1998). The servant king, the Bibles Portrait of the Messiah, Guernsey: Inter-varsity Press

2. Anyacho, E. O. (2003). Religion in Society: An Introduction to EcoTheology and Justice, Nnobi: C.P. Globe

3. Carson, R. (1962). Silent Spring, Boston: Houghton Muffin

4. Commonwealth Forestry Association (CFA) (2018), "Nigerian Conservation Foundation", Retrieved from http://www.cfainternational.org/NGO\%20directory/DFA-578.htm on $31^{\text {st }}$ October, 2018

5. Dianna, R. Garland (1999). Family Ministry: A Comprehensive Guide, Downers Gove, Illinois: Inter-varsity Press

6. Okeke, G. C (2011), "Human Ecology in Nigeria: A Moral Evaluation", in Nwaigbo, F., Asanbe, J., Ejeh, I., Echema, A., Gangwari, J., Anozie, O. and Nwaoru, E. (eds.). Theology for Sustainable Ecology in Africa, Port Harcourt: Ciwa Publications, pp.171-182

7. Okoro, I. C (2011), "The Oil Industry and the Challenges of Environmental Management and Protection in Nigeria”, in Nwaigbo, F., Asanbe, J., Ejeh, I., Echema, A.,Gangwari, J., Anozie, O. 
and Nwaoru, E. (eds.). Theology for Sustainable Ecology in Africa, Port Harcourt: Ciwa Publications, pp.28-42

8. Oyeshola, D (1995). Essential of Environmental Issue: The World and Nigeria in Perspective, Ibadan: Daily Graphics Publication

9. Terence, E. F (1969). Creation, Fall and Flood: Studies in Genesis 1:11, Minnea polis, Minnesota: Augsburg Publication House

10. Ukwuije, B. U (2010), "Befriending the Earth: Towards a Doxological Approach to the Environment", in African Journal of Contextual Theology (AJCT), Vol.2, June, 2010, Pp.17-27

11. Umoren, A. I (2011), "Paul's Exhortation to Orderliness and Silence in 1Cor.1:26-40 and Noise Pollution from Churches in Nigeria", in Nwaigbo, F., Asanbe, J., Ejeh, I., Echema, A., Gangwari, J., Anozie, O. and Nwaoru, E. (eds.). Theology for Sustainable Ecology in Africa, Port Harcourt: Ciwa Publications, pp.141-149

12. Vine, W.E. Merrily, F. U and William, W. J. R (2007). Vines Complete Expository Dictionary of Old and New Testament Words, Nastiville: Thomas Nelson Publication 